\title{
Bioedusiana
}

Blölogy

Education

Department

Universitas Siliwang http://jurnal.unsil.ac.id/index.php/bioed

DOI: https://doi.org/10.37058/bioed.v6i2.3948

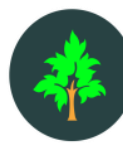

Bioedusiana

Jurnal Pendidikan Biologi

\section{Persepsi Mahasiswa terhadap Pembelajaran Jarak Jauh Berbasis Proyek pada Mata Kuliah Game Learning pada Masa Pandemi COVID-19}

\section{Students' Perception to Distance Project-based Learning on Game Learning Course during COVID- 19 Pandemic}

\author{
Chandra Adi Prabowo ${ }^{1}$, Sri Dwiastuti ${ }^{2}$, Samuel Agus Triyanto ${ }^{3 *}$ \\ ${ }^{1,2}$ Pendidikan Biologi, Universitas Sebelas Maret, J1. Ir. Sutami 36 A, Surakarta, 57126, Indonesia \\ ${ }^{3}$ Pendidikan Biologi, Universitas Siliwangi, Jl. Siliwangi No.24, Tasikmalaya, 46115, Indonesia
}

\begin{abstract}
Abstrak
Mata kuliah Game Learning adalah mata kuliah berbasis proyek berupa pembuatan desain pembelajaran serta media pembelajaran game edukasi. Namun, pembelajaran berbasis proyek merupakan salah satu strategi pembelajaran yang cukup menantang untuk diterapkan dalam pembelajaran jarak jauh. Oleh karena itu, kita perlu mengetahui persepsi mahasiswa terhadap untuk meningkatkan kualitas pembelajaran. Penelitian ini bertujuan untuk mengetahui persepsi mahasiswa terhadap pembelajaran jarak jauh berbasis proyek yang diselenggarakan selama masa pandemi COVID19. Penelitian ini menggunakan metode campuran (mixed method) dengan rancangan explanatory. Data kuantitatif dan kualitatif dikumpulkan menggunakan instrumen angket, wawancara, dan observasi. Subjek penelitian adalah 25 mahasiswa peserta mata kuliah Game Learning yang menggunakan strategi pembelajaran berbasis proyek yang dilaksanakan pada semester genap 2020/2021. Hasil penelitian menunjukkan pembelajaran berbasis proyek efektif diterapkan dalam pembelajaran jarak jauh dengan beberapa keterbatasan. Kesimpulannya adalah pembelajaran berbasis proyek dapat diterapkan dalam pembelajaran jarak jauh dengan merancang sesuai dengan kebutuhan pembelajaran untuk memastikan setiap anggota kelompok dapat berkontribusi terhadap proyek secara efektif.
\end{abstract}

Kata kunci: Pembelajaran Berbasis Proyek; Pembelajaran Jarak Jauh; Persepsi Mahasiswa

\section{Abstract}

Game Learning courses are project-based courses in the form of making learning designs and learning media for educational games. However, project-based learning is one of the most challenging learning strategies to be applied in distance learning. Therefore, we need to know students' perceptions of improving the quality of learning. This study aims to determine student perceptions of projectbased distance learning held during the COVID-19 pandemic. We use a mixed method (mixed method) with an explanatory design. Quantitative and qualitative data were collected using questionnaires, interviews, and observation instruments. The research subjects were 25 students participating in the Game Learning course who used project-based learning strategies which were carried out in the academic year of 2020/2021. The results showed that project-based learning was effectively applied in distance learning with some limitations. The conclusion is that project-based learning can be applied in distance learning by ensuring that each group member can contribute to the project effectively.

Keywords: Project-Based Learning; Distance Learning; Student's Perception

\section{Article History}

Received: November 26 $6^{\text {th }}, 2021$; Accepted: December 28 ${ }^{\text {th }}, 2021$; Published: December $31^{\text {st }}, 2021$

Corresponding Author*

Samuel Agus Triyanto, Pendidikan Biologi, Universitas Siliwangi, E-mail: samuel.agus@unsil.ac.id 


\section{PENDAHULUAN}

Strategi pembelajaran merupakan salah satu aspek utama dalam proses pembelajaran yang menentukan ketercapaian tujuan pembelajaran. Menteri Pendidikan dan Kebudayaan melalui Permendikbud Nomor 22 Tahun 2016 tentang Standar Proses menyarankan untuk menggunakan strategi pembelajaran berbasis tematik, saintifik, inkuiri, discovery, atau proyek sesuai dengan karakteristik kompetensi dan jenjang pendidikan. Namun, pandemi COVID-19 membuat kita harus melakukan pembatasan interaksi fisik untuk mencegah penyebaran virus sehingga proses pembelajaran harus dilaksanakan secara jarak jauh atau daring.

Pembelajaran jarak jauh menjadi tantangan bagi pendidik untuk dapat membantu peserta didik mencapai tujuan pembelajaran tanpa bertemu secara langsung di kelas. Kondisi tersebut menyebabkan strategi pembelajaran yang biasanya digunakan perlu disesuaikan dengan karakteristik pembelajaran jarak jauh. Hasil penelitian Krishan et al. (2020) menunjukkan selama masa pandemi COVID-19 banyak pendidik yang menggunakan strategi pembelajaran tradisional seperti ceramah dalam pembelajaran jarak jauh. Kondisi ini menurut Jin et al. (2021) disebabkan keterbatasan interaksi dalam pembelajaran jarak jauh. Salah satu aspek fundamental dari strategi pembelajaran tradisional adalah umumnya bersifat berorientasi pada guru (teacher-centered learning).

Metode pembelajaran tradisional seperti ceramah yang bersifat berorientasi pada guru dapat dilakukan pada beberapa kondisi pembelajaran. Namun, pembelajaran yang berorientasi pada guru (teacher-centered learning) membuat pengetahuan yang diperoleh siswa tidak bertahan lama serta tidak bermakna (Hafeez, 2021). Kondisi ini menyebabkan pembelajaran jarak jauh menjadi tidak efektif dan tidak dapat mencapai tujuan pembelajaran yang diharapkan. Oleh karena itu, pendidik perlu merancang strategi pembelajaran yang efektif serta melibatkan siswa sebagai pusat pembelajaran (student-centered learning) dalam pembelajaran jarak jauh.

Pembelajaran berbasis proyek atau Project-based Learning (PjBL) merupakan sebuah strategi pembelajaran berorientasi pada siswa yang diketahui lebih efektif dibandingkan pembelajaran tradisional (Hafeez, 2021). Menurut Burns \& Herring (2020) pembelajaran berbasis proyek lebih efektif dibandingkan strategi pembelajaran lain dalam meningkatkan capaian akademik serta mengembangkan keterampilan berpikir tingkat tinggi. Pembelajaran berbasis proyek juga terbukti dapat mengembangkan keterampilan kolaborasi siswa (Owens \& Hite, 2020; Trisdiono et al., 2019). Berbagai hasil penelitian tersebut menjadi dasar acuan untuk menerapkan pembelajaran berbasis proyek dalam kegiatan pembelajaran khususnya pada pembelajaran yang berorientasi pada proyek seperti mata kuliah Game Learning.

Berbagai hasil penelitian di atas menjadi alasan PjBL menjadi salah satu strategi pembelajaran yang paling banyak digunakan dalam pembelajaran. Namun, data mengenai aplikasi pembelajaran berbasis proyek dalam pembelajaran daring masih sangat sedikit khususnya 
di Indonesia yang memiliki kualitas infrastruktur jaringan internet terbatas dan belum merata antara satu daerah dengan daerah lainnya sehingga pembelajaran jarak jauh masih menjadi tantangan tersendiri.

Merancang pembelajaran yang berorientasi pada siswa seperti PjBL khususnya dalam pembelajaran jarak jauh memerlukan banyak pertimbangan. Berbagai faktor yang mempengaruhi seperti ketersediaan sarana dan prasarana, keterampilan pendidik dan peserta didik dalam memanfaatkan teknologi, serta kesesuaian dengan kurikulum pembelajaran perlu diperhatikan dengan seksama agar tujuan pembelajaran dapat tercapai. Salah satu cara untuk mengevaluasi keberhasilan proses pembelajaran adalah dengan mengumpulkan respon dan persepsi peserta didik (Martin et al., 2020). Oleh karena itu, pengumpulan data mengenai persepsi peserta didik terhadap pembelajaran berbasis proyek dalam pembelajaran jarak jauh penting untuk dilakukan sebagai upaya untuk meningkatkan kualitas pembelajaran khususnya selama masa pandemi COVID-19.

\section{METODE}

Penelitian ini menggunakan metode penelitian campuran (mixed method) dengan rancangan sequential explanatory (Cresswell, 2012). Tahapan penelitian dimulai dengan pengumpulan data kuantitatif kemudian dilanjutkan pengumpulan data kualitatif sesuai dengan hasil analisis data kuantitatif untuk memperoleh informasi lebih mendalam dan menjelaskan mengenai persepsi mahasiswa terhadap pembelajaran jarak jauh berbasis proyek. Penelitian dilaksanakan di Program Studi Pendidikan Biologi FKIP Universitas Sebelas Maret pada bulan Maret-Juli 2021. Subjek penelitian ini adalah seluruh mahasiswa yang mengikuti mata kuliah Game Learning pada semester genap tahun akademik 2020/2021 berjumlah 25 mahasiswa. Mahasiswa peserta mata kuliah ini berasal dari beberapa universitas negeri di Indonesia yang mengikuti program pertukaran mahasiswa sehingga memiliki latar belakang demografi yang beragam.

Data penelitian dikumpulkan melalui beberapa metode yang berbeda untuk menjamin validitas data hasil penelitian yang meliputi observasi kegiatan pembelajaran, survey, dan wawancara dengan kisi-kisi instrumen disajikan pada Tabel 1. Selama pembelajaran berlangsung dilakukan observasi untuk mengetahui jalannya kegiatan diskusi dan pengerjaan proyek oleh mahasiswa. Survei dilakukan menggunakan angket respon mahasiswa berbasis skala Likert untuk mengumpulkan data kuantitatif yang diisi oleh mahasiswa secara daring setelah kegiatan perkuliahan. Angket yang digunakan memuat pertanyaan mengenai pendapat mahasiswa mengenai proses pembelajaran serta proyek yang dikerjakan. Angket berupa item pertanyaan skala Likert lima tingkat dianalisis menggunakan statistik deskriptif yang meliputi frekuensi dan persentase. Lima kriteria skala Likert yang digunakan meliputi 1=Sangat Tidak Setuju, $2=$ Tidak 
Setuju, 3=Ragu-Ragu, 4=Setuju, dan 5=Sangat Setuju. Kegiatan wawancara dilakukan berdasarkan hasil observasi pembelajaran dan survei untuk mengumpulkan data kualitatif penelitian. Data kualitatif yang dikumpulkan berupa penjelasan lebih mendalam mengenai persepsi mahasiswa terhadap pembelajaran jarak jauh berbasis proyek. Melalui kombinasi ketiga metode pengumpulan dan jenis data tersebut diharapkan dapat diperoleh informasi yang lebih akurat terhadap persepsi mahasiswa.

Tabel 1. Kisi-Kisi Instrumen Penelitian

\begin{tabular}{crc}
\hline No & Indikator & Instrumen \\
\hline 1 & Efektivitas pembelajaran & Lembar observasi, angket \\
2 & Kesulitan pengerjaan proyek & Lembar observasi, angket \\
3 & Antusiasme mahasiswa dalam pembelajaran & Angket \\
4 & Tantangan & Lembar observasi, angket \\
5 & Pengalaman baru yang diperoleh & Angket \\
6 & Pendapat umum terhadap pembelajaran & Wawancara \\
7 & Konten materi & Wawancara \\
8 & Konektivitas pembelajaran & Wawancara \\
9 & Interaksi & Wawancara \\
10 & Fleksibilitas & Wawancara \\
11 & Evaluasi & Wawancara \\
\hline
\end{tabular}

\section{HASIL DAN PEMBAHASAN}

Hasil

Hasil penelitian memuat tiga data utama yang meliputi data observasi pembelajaran, survei, dan wawancara. Setiap data yang dikumpulkan dalam penelitian ini saling terkait dan mendukung untuk memperoleh informasi secara mendalam.

\section{Deskripsi hasil observasi pembelajaran}

Kegiatan observasi dilakukan selama 12 jam aktivitas pembelajaran yang dilaksanakan dalam enam pekan. Fokus observasi adalah pada kegiatan diskusi mahasiswa ketika menyelesaikan proyek pembuatan desain pembelajaran berbasis game (game-based learning) dan media pembelajaran game edukasi yang menjadi luaran dalam perkuliahan Game Learning. Kegiatan pembelajaran diawali dengan pembahasan materi melalui diskusi kelas kemudian dilanjutkan diskusi secara berkelompok dengan memanfaatkan fitur Breakout Room pada aplikasi Zoom Meeting ${ }^{\circledR}$ kemudian dosen melakukan pendampingan dan memantau kerja kelompok secara bergantian.

Secara umum, kegiatan diskusi proyek selama kegiatan pembelajaran dapat berjalan dengan baik. Namun, terdapat beberapa kejadian yang menjadi catatan peneliti seperti terdapat mahasiswa yang kurang dapat berpartisipasi secara efektif karena terkendala teknis seperti permasalahan jaringan yang tidak stabil, kendala ketika membagikan layar, kolaborasi pengerjaan 
proyek, serta terdapat sebagian kecil anggota yang mematikan kamera dan tidak terlibat aktif dalam proses diskusi. Berbagai kendala tersebut menjadi acuan dalam penyusunan instrumen angket persepsi mahasiswa untuk mengetahui akar permasalahan yang dialami selama mengikuti pembelajaran jarak jauh berbasis proyek.

\section{Analisis Hasil Survei Persepsi Mahasiswa}

Survei dilakukan menggunakan angket persepsi mahasiswa terhadap pembelajaran berbasis proyek yang memuat beberapa informasi seperti demografi, efektivitas pembelajaran, kesulitan pengerjaan proyek, keberhasilan proyek, efektivitas kerja kelompok, antusiasme mahasiswa terhadap pembelajaran, tantangan, serta pengalaman baru yang diperoleh. Frekuensi dan persentase capaian dari setiap pernyataan dihitung dan hasilnya disajikan pada Tabel 2 .

Tabel 2. Hasil Survei Persepsi Mahasiswa Terhadap Pembelajaran Jarak Jauh Berbasis Proyek

\begin{tabular}{lccccc}
\hline \multirow{2}{*}{ Pernyataan } & \multicolumn{5}{c}{ Persentase Respon (\%) } \\
\cline { 2 - 6 } & $\mathbf{1}$ & $\mathbf{2}$ & $\mathbf{3}$ & $\mathbf{4}$ & $\mathbf{5}$ \\
\hline $\begin{array}{l}\text { P1 - Mata kuliah berbasis proyek ini efektif dilaksanakan secara } \\
\text { daring }\end{array}$ & 23.34 & 21.00 & 28.45 & 9.26 & 17.45 \\
$\begin{array}{l}\text { P2 - Saya mengharapkan pembelajaran jarak jauh } \\
\text { dilaksanakan dengan jadwal yang sangat terstruktur seperti }\end{array}$ & 25.38 & 26.73 & 21.50 & 19.17 & 7.22 \\
pembelajaran di kelas & & & & & \\
$\begin{array}{l}\text { P3 - Pembelajaran jarak jauh secara daring membuat } \\
\text { komunikasi dengan dosen dan mahasiswa lain menjadi lebih } \\
\text { mudah }\end{array}$ & 31.27 & 31.60 & 14.33 & 8.47 & 14.33 \\
$\begin{array}{l}\text { P4 - Saya lebih nyaman berdiskusi kelompok secara daring } \\
\text { daripada bertatap muka }\end{array}$ & 15.96 & 26.38 & 21.50 & 19.94 & 16.22 \\
$\begin{array}{l}\text { P5 - Keterampilan saya dalam memanfaatkan berbagai } \\
\text { platform kolaborasi daring meningkat sejak mengikuti }\end{array}$ & 12.66 & 14.38 & 23.45 & 31.60 & 19.30 \\
pembelajaran ini \\
$\begin{array}{l}\text { P6 - Kerja kelompok untuk penyelesaian proyek dapat berjalan } \\
\text { dengan efektif }\end{array}$ & 15.48 & 20.31 & 25.73 & 15.64 & 15.85 \\
$\begin{array}{l}\text { P7 - Dosen memahami dengan baik cara mengelola kelas } \\
\text { daring sehingga proses belajar menjadi lebih mudah }\end{array}$ & 14.85 & 20.98 & 30.62 & 21.73 & 11.82 \\
\hline
\end{tabular}

Analisis lebih lanjut dilakukan untuk mengetahui adanya pola pada data yang dikumpulkan menggunakan uji Friedman. Tingkatan dari data responden dimungkinkan bersifat acak tanpa pola tertentu sehingga membandingkannya secara langsung berdasarkan rerata/mean rank berpotensi untuk menimbulkan kesalahan penafsiran. Sehingga, rerata dapat dibandingkan hanya setelah dipastikan bahwa terdapat pola dari data yang diperoleh dari responden. Hasil perhitungan menunjukkan terdapat pola pada data yang diketahui berdasarkan hasil perhitungan statistik diperoleh hasil signifikan. Rerata dari setiap item pernyataan digunakan untuk pemeringkatan pernyataan terkait persepsi mahasiswa terhadap pembelajaran jarak jauh berbasis proyek. Hasil analisis menunjukkan bahwa peningkatan keterampilan kolaborasi, pemahaman 
dosen dalam memahami kelas daring, dan efektivitas kerja kelompok memperoleh capaian tertinggi (Tabel 3). Hasil perhitungan statistik disajikan pada Tabel 4 dan berdasarkan tingkat signifikansinya mengindikasikan perbedaan antar item pertanyaan sangat signifikan.

Tabel 3. Pemeringkatan Capaian Item Pernyataan Berdasarkan Uji Friedman

\begin{tabular}{cc}
\hline Peringkat Item Pernyataan & Peringkat Rerata/Mean Rank \\
\hline P1 & 3.92 \\
P2 & 3.56 \\
P3 & 3.23 \\
P4 & 4.06 \\
P5 & 4.78 \\
P6 & 4.22 \\
P7 & 4.26 \\
\hline
\end{tabular}

Tabel 4. Hasil Uji Peringkat Friedman

\begin{tabular}{cc}
\hline Uji statistik & Nilai \\
\hline N & 25 \\
Chi-Square & 129.88 \\
Df & 6 \\
Asymp. Sig. & .00 \\
\hline
\end{tabular}

\section{Data Hasil Wawancara}

Wawancara dilakukan berdasarkan temuan pada hasil kegiatan observasi pembelajaran dan survei persepsi mahasiswa untuk memperoleh informasi yang lebih mendalam khususnya mengenai ekspektasi dan masukan mahasiswa terhadap pembelajaran jarak jauh berbasis proyek. Terdapat beberapa respon yang berhasil peneliti kumpulkan dari responden yang dikategorikan menjadi beberapa indikator meliputi pendapat umum, konten materi, konektivitas, interaksi, fleksibilitas, dan evaluasi. Deskripsi indikator dan hasil wawancara disajikan pada Tabel 5 dan Tabel 6.

Mayoritas responden berpendapat bahwa pembelajaran jarak jauh berbasis proyek yang dilaksanakan efektif karena proses pembelajaran dilaksanakan secara terstruktur dan interaktif. Selain itu, sebagian besar responden menyatakan kurikulum pembelajaran serta metode komunikasi yang fleksibel membuat mahasiswa mampu menyelesaikan proyek dengan baik. Namun, kendala jaringan internet serta keterbatasan spesifikasi perangkat teknologi yang digunakan seperti komputer dan telepon pintar membuat terdapat mahasiswa yang mengalami kesulitan dalam berpartisipasi dalam kerja dan diskusi kelompok. 
Tabel 5. Indikator Respon dan Masukan yang Diperoleh dari Wawancara

\begin{tabular}{|c|c|c|}
\hline Indikator & Kriteria & Contoh Respon \\
\hline Umum & $\begin{array}{l}\text { Komentar umum terhadap proses } \\
\text { pembelajaran }\end{array}$ & $\begin{array}{l}\text { Pembelajaran jarak jauh berbasis proyek seperti ini } \\
\text { merupakan metode yang inovatif serta jarang } \\
\text { ditemukan pada pembelajaran lain }\end{array}$ \\
\hline Konten & Materi yang disajikan oleh dosen & $\begin{array}{l}\text { Tambahkan pelatihan penggunaan game engine } \\
\text { untuk pembuatan game digital }\end{array}$ \\
\hline Konektivitas & Akses internet & $\begin{array}{l}\text { Kehadiran seharusnya juga memperhitungkan } \\
\text { mahasiswa yang mengalami kendala jaringan } \\
\text { internet namun tetap berkontribusi dalam proyek }\end{array}$ \\
\hline Interaksi & $\begin{array}{l}\text { Partisipasi aktif dosen dan } \\
\text { mahasiswa }\end{array}$ & $\begin{array}{l}\text { Dosen perlu lebih memastikan setiap mahasiswa } \\
\text { terlibat aktif dalam pembelajaran }\end{array}$ \\
\hline Fleksibilitas & $\begin{array}{l}\text { Kenyamanan selama mengikuti } \\
\text { proses pembelajaran }\end{array}$ & $\begin{array}{l}\text { Mahasiswa memerlukan tambahan waktu lebih } \\
\text { banyak untuk dapat menyelesaikan tugas atau } \\
\text { mempelajari suatu konsep yang cukup kompleks }\end{array}$ \\
\hline Evaluasi & $\begin{array}{l}\text { Metode evaluasi proses dan hasil } \\
\text { pembelajaran serta umpan balik } \\
\text { yang diterima oleh mahasiswa }\end{array}$ & $\begin{array}{l}\text { Metode tes yang digunakan sebaiknya proporsinya } \\
\text { tidak lebih besar dari nilai proyek yang lebih } \\
\text { banyak menghabiskan waktu pengerjaannya }\end{array}$ \\
\hline
\end{tabular}

Tabel 6. Frekuensi Indikator yang Diperoleh dari Responden

\begin{tabular}{cc}
\hline Indikator & Jumlah Respon $(\mathbf{n}=\mathbf{2 5})$ \\
\hline Umum & 22 \\
Konten & 12 \\
Konektivitas & 4 \\
Interaksi & 5 \\
Fleksibilitas & 10 \\
Evaluasi & 4 \\
\hline
\end{tabular}

\section{Pembahasan}

Pembelajaran jarak jauh secara umum telah dapat diterima oleh sebagian besar responden dalam penelitian ini sebagai metode pembelajaran yang paling sesuai untuk menghadapi pandemi COVID-19 yang saat ini sedang terjadi. Namun, terdapat beragam persepsi terkait pelaksanaan pembelajaran jarak jauh khususnya pada strategi pembelajaran yang umumnya dilakukan secara tatap muka di kelas. Oleh karena itu, informasi mengenai persepsi peserta didik terhadap pembelajaran jarak jauh perlu untuk diungkap dalam rangka meningkatkan kualitas proses pembelajaran (Martin et al., 2020).

Penelitian mengenai persepsi peserta didik terhadap pembelajaran jarak jauh saat ini telah banyak dilakukan pada penelitian sebelumnya (Bali \& Liu, 2018; Fedynich et al., 2015; Surani \& Hamidah, 2020). Indikator persepsi terhadap pembelajaran yang teridentifikasi dari responden penelitian sejalan dengan hasil penelitian sebelumnya. Salah satu faktor yang sangat menentukan keberhasilan pembelajaran jarak jauh adalah pemahaman pendidik terhadap proses belajar jarak jauh serta struktur dari proses pembelajaran. Temuan ini menguatkan hasil penelitian sebelumnya oleh (Cole et al., 2021). Karakteristik pembelajaran jarak jauh yang fleksibel dapat dimanfaatkan untuk memberikan kesempatan yang lebih besar bagi peserta didik belajar lebih mendalam karena 
dapat menyesuaikan waktunya sesuai kebutuhan. Pembelajaran secara daring dalam durasi panjang seperti pembelajaran di kelas perlu dihindari karena akan menyebabkan kelelahan serta gangguan fisik yang diakibatkan penggunaan perangkat elektronik.

Diskusi kelompok adalah salah satu komponen utama dalam pembelajaran berbasis proyek. Hal ini sesuai dengan temuan Hsu \& Shiue (2018) yang membuktikan bahwa kegiatan diskusi kelompok memiliki peran penting dalam keberhasilan proyek. Pembelajaran jarak jauh membuat kegiatan diskusi membutuhkan bantuan teknologi. Oleh karena itu, penguasaan berbagai platform digital penunjang proses diskusi menjadi salah satu faktor krusial. (Fidiastuti et al., 2019) menyatakan bahwa literasi digital yang baik menjadi sebuah keharusan dalam mencapai keberhasilan pembelajaran yang memberdayakan keterampilan berpikir tingkat tinggi dan diskusi seperti pembelajaran berbasis proyek.

Teknologi dapat meningkatkan intensitas komunikasi karena dapat dilakukan secara lebih fleksibel (Orr et al., 2019). Namun, terdapat persepsi yang berlawanan dari responden penelitian ini yang menyatakan bahwa kegiatan interaksi lebih mudah dilakukan secara tatap muka dibandingkan secara daring dengan perantara teknologi. Pernyataan tersebut dikuatkan dengan pernyataan Diep et al. (2017) yang mengatakan bahwa interaksi secara daring umumnya lebih baik secara intensitas namun menurun secara kualitas. Permasalahan tersebut tejadi karena adanya kendala dalam penggunaan alat serta infrastruktur misalnya jaringan internet yang tidak stabil sehingga menyebabkan kendala dalam proses interaksi. Menurut Cesari et al. (2021) kendala menurunnya kualitas interaksi dapat diatasi dengan penguasaan teknologi komunikasi sehingga keterbatasan tersebut dapat diatasi.

Faktor penting dalam keberhasilan pembelajaran jarak jauh berbasis proyek salah satunya adalah pemahaman pendidik dalam memanfaatkan kelebihan serta meminimalisir pembelajaran jarak jauh. Hafeez (2021) menemukan bahwa masih terdapat banyak kesalahan pendidik dalam memanfaatkan pembelajaran daring khususnya selama masa pandemi COVID-19 saat ini dengan memindahkan strategi pembelajaran tatap muka dalam pembelajaran jarak jauh. Pembelajaran Game Learning dalam penelitian ini mengkombinasikan pembelajaran jarak jauh secara sinkronis dan asinkronis. Kegiatan sinkronis dilakukan dalam durasi pendek untuk menghindari kelelahan peserta didik dalam menggunakan perangkat elektronik. Hal ini didasarkan pada temuan Oducado \& Estoque (2021) yang menyatakan salah satu penyebab stres peserta didik selama masa pandemi COVID-19 ini adalah kelelahan fisik akibat terlalu lama mengikuti kelas daring dengan perangkat elektronik seperti komputer, tablet, atau telepon pintar. Kegiatan asinkronis diterapkan untuk memberikan kesempatan pada peserta didik dapat belajar secara lebih fleksibel sesuai waktu yang dikehendaki. Dampak dari penerapan kombinasi strategi pembelajaran jarak jauh ini adalah peserta didik menjadi lebih menikmati proses belajar. 
Pandemi COVID-19 telah secara tidak langsung memaksa dunia pendidikan untuk mengimplementasikan pembelajaran jarak jauh secara penuh dengan memanfaatkan teknologi. Pembelajaran jarak jauh secara penuh sebelum pandemi terjadi bahkan belum pernah dilakukan di negara maju sekalipun. Beragam alasan meliputi berbagai keuntungan pembelajaran tatap muka, umpan balik yang lebih cepat, dan rasa kebersamaan. Salah satu alasan besar lainnya adalah terkait dengan kesulitan yang dihadapi pendidik dalam mengajar secara jarak jauh. Bidang ilmu pendidikan biologi yang kegiatan pembelajarannya didominasi oleh praktik dan kegiatan lapangan menjadi salah satu bidang ilmu yang perlu mengembangkan strategi pembelajaran agar peserta didik tetap dapat mengaplikasikan pengetahuan yang dimiliki dalam upaya penyelesaian masalah. Temuan dari penelitian diharapkan dapat menjadi salah satu acuan dalam merancang dan mengaplikasikan pembelajaran jarak jauh yang lebih efektif.

\section{SIMPULAN}

Pembelajaran jarak jauh saat ini menjadi strategi pembelajaran utama dalam dunia pendidikan dalam upaya menghentikan penyebaran novel coronavirus dengan mengurangi interaksi secara langsung (physical distancing). Institusi pendidikan harus melakukan perubahan baik secara proses maupun perencanaan pembelajaran untuk dapat mencapai tujuan pembelajaran dari kurikulum yang telah ditetapkan. Saat ini masih terlalu awal untuk dapat menyimpulkan bahwa pembelajaran jarak jauh telah berhasil diimplementasikan karena masih banyaknya kekurangan dan kendala yang terjadi. Namun, persepsi peserta didik terhadap pembelajaran jarak jauh yang telah diimplementasikan adalah sebuah informasi berharga untuk meningkatkan kualitas pembelajaran khususnya pada masa pandemi COVID-19 saat ini.

Berbagai bukti dan temuan dari penelitian ini mengindikasikan sebagian besar peserta didik memiliki persepsi yang positif terhadap pembelajaran jarak jauh berbasis proyek selama masa pandemi. Pembelajaran jarak jauh dianggap memiliki banyak keuntungan seperti fleksibilitas dan kenyamanan dalam mengikuti proses pembelajaran. Peserta didik menginginkan pembelajaran jarak jauh yang terstruktur namun tetap dapat diakses kapan saja. Selain itu, pada aspek penilaian peserta didik juga meminta untuk memberikan proporsi lebih besar pada proyek dibandingkan tes tertulis karena memerlukan upaya yang lebih berat. Tantangan yang dihadapi adalah rendahnya kualitas interaksi karena berbagai keterbatasan komunikasi secara daring. Peserta didik juga lebih mengharapkan untuk lebih mempertimbangkan kontribusi pekerjaan dalam penyelesaian proyek dibandingkan hanya melihat kehadiran dalam kelas daring karena banyaknya kendala dan keterbatasan khususnya dalam aspek sarana dan prasarana. Berdasarkan berbagai simpulan tersebut, penelitian ini membuktikan pentingnya merancang pembelajaran jarak jauh yang secara karakteristik memiliki perbedaan mendasar dengan pembelajaran tatap muka khususnya pada aspek interaksi. 


\section{REFERENSI}

Bali, S., \& Liu, M. C. (2018). Students' perceptions toward online learning and face-to-face learning courses. Journal of Physics: Conference Series. https://doi.org/10.1088/17426596/1108/1/012094

Burns, A. M., \& Herring, C. (2020). Project-based learning. In Using Technology with Elementary Music Approaches. https://doi.org/10.1093/oso/9780190055653.003.0009

Cesari, V., Galgani, B., Gemignani, A., \& Menicucci, D. (2021). Enhancing qualities of consciousness during online learning via multisensory interactions. Behavioral Sciences. https://doi.org/10.3390/bs11050057

Cole, A. W., Lennon, L., \& Weber, N. L. (2021). Student perceptions of online active learning practices and online learning climate predict online course engagement. Interactive Learning Environments. https://doi.org/10.1080/10494820.2019.1619593

Cresswell, J. . (2012). Educational Research: Planning, Conducting, and Evaluating Quantitative and Qualitative Research. Pearson.

Diep, N. A., Cocquyt, C., Zhu, C., \& Vanwing, T. (2017). Online interaction quality among adult learners: The role of sense of belonging and perceived learning benefits. Turkish Online Journal of Educational Technology.

Fedynich, L., Bradley, K. S., \& Bradley, J. (2015). Graduate students' perceptions of online learning. Research in Higher Education Journal.

Fidiastuti, H. R., Prabowo, C. A., \& Bariska, H. F. (2019). Pojok Digital: Upaya untuk Meningkatkan Motivasi Belajar dan Pengenalan Literasi Baru pada Siswa SD Negeri 2 Pujiharjo. JAST: Jurnal Aplikasi Sains Dan Teknologi, 3(2), 102. https://doi.org/10.33366/jast.v3i2.1417

Hafeez, M. (2021). Project-Based Versus Traditional Lecture Teaching Methods. EDUTEC: Journal of Education And Technology. https://doi.org/10.29062/edu.v4i4.220

Hsu, Y. C., \& Shiue, Y. M. (2018). Exploring the influence of using collaborative tools on the community of inquiry in an interdisciplinary project-based learning context. Eurasia Journal of Mathematics, Science and Technology Education. https://doi.org/10.12973/ejmste/81149

Jin, Y. Q., Lin, C. L., Zhao, Q., Yu, S. W., \& Su, Y. S. (2021). A Study on Traditional Teaching Method Transferring to E-Learning Under the Covid-19 Pandemic: From Chinese Students' Perspectives. Frontiers in Psychology. https:// doi.org/10.3389/fpsyg.2021.632787

Krishan, I. A., Ching, H. S., Ramalingam, S., Maruthai, E., Kandasamy, P., Mello, G. De, Munian, S., \& Ling, W. W. (2020). Challenges of Learning English in 21st Century: Online vs. Traditional During Covid-19. Malaysian Journal of Social Sciences and Humanities (MJSSH). https://doi.org/10.47405/mjssh.v5i9.494

Martin, F., Stamper, B., \& Flowers, C. (2020). Examining student perception of readiness for online learning: Importance and confidence. Online Learning Journal. https://doi.org/10.24059/olj.v24i2.2053

Oducado, R. M. F., \& Estoque, H. (2021). Online Learning in Nursing Education During the COVID-19 Pandemic: Stress, Satisfaction, and Academic Performance. Journal Of Nursing Practice. https://doi.org/10.30994/jnp.v4i2.128

Orr, D., Weller, M., \& Farrow, R. (2019). How is digitalisation affecting the flexibility and openness of higher education provision? Results of a global survey using a new conceptual model. Journal of Interactive Media in Education. https://doi.org/10.5334/jime.523

Owens, A. D., \& Hite, R. L. (2020). Enhancing student communication competencies in STEM using virtual global collaboration project based learning. Research in Science and Technological Education. https://doi.org/10.1080/02635143.2020.1778663 
Surani, D., \& Hamidah, H. (2020). Students Perceptions in Online Class Learning During the Covid-19 Pandemic. International Journal on Advanced Science, Education, and Religion. https://doi.org/10.33648/ijoaser.v3i3.78

Trisdiono, H., Siswandari, S., Suryani, N., \& Joyoatmojo, S. (2019). Multidisciplinary integrated project-based learning to improve critical thinking skills and collaboration. International Journal of Learning, Teaching and Educational Research. https://doi.org/10.26803/ijlter.18.1.2 